\title{
Metal (II) Complexes Derived from Naphthofuran-2-carbohydrazide and Diacetylmonoxime Schiff Base: Synthesis, Spectroscopic, Electrochemical, and Biological Investigation
}

\author{
R. B. Sumathi and M. B. Halli \\ Department of Chemistry, Gulbarga University, Gulbarga, Karnataka 585106, India \\ Correspondence should be addressed to M. B. Halli; mbhalli@rediffmail.com
}

Received 30 April 2013; Accepted 11 December 2013; Published 30 January 2014

Academic Editor: Concepción López

Copyright (C) 2014 R. B. Sumathi and M. B. Halli. This is an open access article distributed under the Creative Commons Attribution License, which permits unrestricted use, distribution, and reproduction in any medium, provided the original work is properly cited.

A new Schiff base and a new series of $\mathrm{Co}(\mathrm{II}), \mathrm{Ni}(\mathrm{II}), \mathrm{Cu}(\mathrm{II}), \mathrm{Cd}(\mathrm{II})$, and $\mathrm{Hg}(\mathrm{II})$ complexes were synthesized by the condensation of naphthofuran-2-carbohydrazide and diacetylmonoxime. Metal complexes of the Schiff base were prepared from their chloride salts of $\mathrm{Co}(\mathrm{II}), \mathrm{Ni}(\mathrm{II}), \mathrm{Cu}(\mathrm{II}), \mathrm{Cd}(\mathrm{II})$, and $\mathrm{Hg}(\mathrm{II})$ in ethanol. The ligand along with its metal complexes have been characterized on the basis of analytical data, IR, electronic, mass, ${ }^{1} \mathrm{HNMR}$, ESR spectral data, thermal studies, magnetic susceptibility, and molar conductance measurements. The nonelectrolytic behaviour of the complexes was assessed from the measured low conductance data. The elemental analysis of the complexes confirm the stoichiometry of the type $\mathrm{CuL}_{2} \mathrm{Cl}_{2}$ and $\mathrm{MLCl}_{2}$ where $\mathrm{M}=\mathrm{Ni}(\mathrm{II}), \mathrm{Co}$ (II), $\mathrm{Cd}(\mathrm{II})$, and $\mathrm{Hg}(\mathrm{II})$ and $\mathrm{L}=\mathrm{Schiff}$ base. The redox property of the $\mathrm{Cu}(\mathrm{II})$ complex was investigated by electrochemical method using cyclic voltammetry. In the light of these results, $\mathrm{Co}(\mathrm{II}), \mathrm{Ni}(\mathrm{II})$, and $\mathrm{Cu}(\mathrm{II})$ complexes are assigned octahedral geometry, $\mathrm{Cd}(\mathrm{II})$, and $\mathrm{Hg}$ (II) complexes tetrahedral geometry. In order to evaluate the effect of metal ions upon chelation, both the ligand and its metal complexes were screened for their antibacterial and antifungal activities by minimum inhibitory concentration (MIC) method. The DNA cleaving capacity of all the complexes was analysed by agarose gel electrophoresis method.

\section{Introduction}

Oxime Schiff base ligand and their metal complexes are cutting-edge areas of research due to their wide variety of applications in bioinorganic chemistry. The chemistry involving oxime moiety is quite diverse [1-3]. Oxime based ligands and their metal complexes in coordination chemistry have been increasingly expanding for their highly valued physicochemical properties, plant growth regulatory activities, reactivity patterns, and potential applications in many significant chemical processes in the field of medicine, bioorganic systems, electrochemical, and electrooptical sensors [4]. Some of the oxime complexes have also exhibited anti-carcinogenic properties [5]. It is known that oxime molecules exhibited greater potency as DNA cleavage agents [6]. Naphthofuran nuclei are key structural moieties found in a large number of biologically important natural products. Many of the natural naphthofurans, such as $( \pm)$-laevigatin $[7],(+)$-heritol $[8,9]$ and balsaminone $\mathrm{A}[10]$, possess interesting pharmacological and cytotoxic properties [11]. A large number of naphthofuran derivatives are endowed with various biological activities like anthelmintic, anticonvulsant, and antipyretic [12] and their plant extracts are being used for traditional medicines [13], while mansonone D and Dunnione [14] of naphthofuran family are vital biologically active agents. In addition, naphthofurans condensed with various heterocycles exhibited wide spectrum of activities [15, 16]. Coordination behaviour of metals have played an important role in the extreme fast development of inorganic chemistry and the presence of metal ions bonded to biologically active compounds may enhance their activity $[17,18]$. The presence of oxygen and nitrogen donor atoms in the complexes shows significant antibacterial and anticancer activities [19].

The interaction of transition metal complexes with nucleic acids is a major area of research due to the utility of these complexes in the design and development of synthetic 

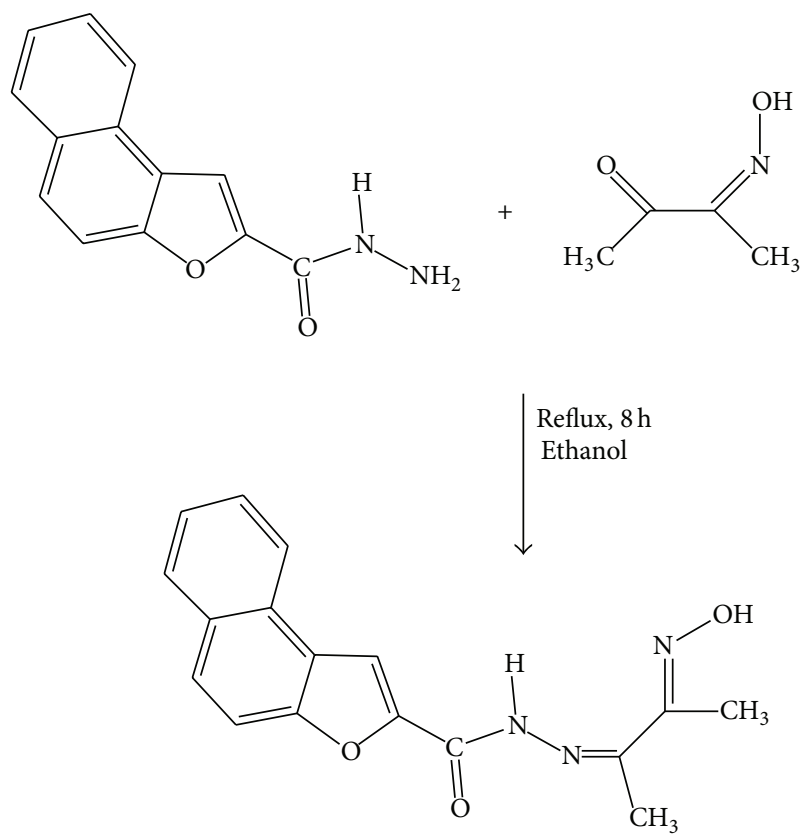

Scheme 1: Synthesis of Schiff base ligand.

restriction enzymes, chemotherapeutic agents, foot printing agents, spectroscopic probes, site-specific cleavers, and molecular photo switches [20].

Prompted by the biological importance and applications of the above compounds in various fields, the present work is devoted to the synthesis and characterization of Schiff base ligand obtained by the condensation of naphthofuran-2carbohydrazide with diacetylmonoxime (Scheme 1) and its metal complexes by using metal ions like $\mathrm{Co}(\mathrm{II}), \mathrm{Ni}(\mathrm{II})$, $\mathrm{Cu}(\mathrm{II}), \mathrm{Cd}(\mathrm{II})$, and $\mathrm{Hg}(\mathrm{II})$. The structural features of the Schiff base and its metal complexes were studied by various spectral analyses and screened for their antimicrobial and DNA cleavage activity studies.

\section{Experimental}

Chemicals and Methods. All chemicals used were of analytical reagent grade, and the solvents were distilled before use. Naphthofuran-2-carbohydrazide was synthesized according to the literature procedure [21]. The metal and chloride contents were determined as per Vogel's procedure [22]. Microanalyses $(\mathrm{C}, \mathrm{H}$, and $\mathrm{N})$ were estimated out on a PerkinElmer 240C model at the Central Drug Research Institute (CDRI), Lucknow. The IR spectra of the ligand and its complexes were recorded on a PerkinElmer 783 FT-IR spectrometer in the $4000-350 \mathrm{~cm}^{-1}$ region in $\mathrm{KBr}$ pellets. The electronic spectra of the $\mathrm{Co}(\mathrm{II}), \mathrm{Ni}(\mathrm{II})$, and $\mathrm{Cu}(\mathrm{II})$ complexes were recorded on a ELICO SL-164 double beam UV-Visible spectrophotometer in the range of $200-1100 \mathrm{~nm}$ in DMF $\left(10^{-4} \mathrm{M}\right)$ solution. The ${ }^{1} \mathrm{H}$ NMR spectra were recorded in DMSO- $d_{6}$ on a BRUKER $500 \mathrm{MHz}$ spectrometer using TMS as an internal reference. The ESR spectrum of the $\mathrm{Cu}$ (II) complex in the polycrystalline state was recorded on a Varian-E-4X band EPR spectrometer using TCNE as the "g" marker ( $\mathrm{g}=2.00277)$ at room temperature. The GC-MS was recorded on a JEOL GC mate mass spectrometer. The DART-MS was recorded on a JEOL-AccuTOF JMS-T100LC mass spectrometer. Thermal analyses were measured from room temperature to $1000^{\circ} \mathrm{C}$ in $\mathrm{N}_{2}$ on a Perkin Elmer, Diamond TG/DTA model thermal analyzer at STIC, Cochin, with a heating rate of $10^{\circ} \mathrm{C} \mathrm{min}^{-1}$. Electrochemistry of the $\mathrm{Cu}$ (II) complex was recorded on a $600 \mathrm{D}$ series model electrochemical analyzer in DMF containing tetrabutylammonium perchlorate as the supporting electrolyte. Molar conductivity measurements were recorded on a ELICO CM-180 conductivity bridge in dry DMF $\left(10^{-3} \mathrm{M}\right)$ solution using a dip-type conductivity cell fitted with a platinum electrode and the magnetic susceptibility measurements were made at room temperature on a Gouy balance using $\mathrm{Hg}\left[\mathrm{Co}(\mathrm{NCS})_{4}\right]$ as the calibrant.

2.1. Synthesis of Schiff Base. A mixture of naphthofuran-2carbohydrazide $(0.01 \mathrm{~mol})$ and diacetylmonoxime $(0.01 \mathrm{~mol})$ in $40 \mathrm{~mL}$ hot ethanolic medium was boiled under reflux for $8-10 \mathrm{~h}$ on a water bath. The light yellowish solid separated on partial evaporation of the solvent and subsequent cooling was filtered, washed with ethanol and finally recrystallized from ethanol. The purity of the Schiff base was checked by TLC:

$$
\mathrm{M} . \mathrm{F}=\mathrm{C}_{17} \mathrm{H}_{15} \mathrm{O}_{3} \mathrm{~N}_{3}, \mathrm{~m} \cdot \mathrm{p}=265^{\circ} \mathrm{C} \text {, yield }=75 \% \text {. }
$$

2.2. Synthesis of $\mathrm{Co}(I I), \mathrm{Ni}(I I), \mathrm{Cu}(I I), \mathrm{Cd}(I I)$, and $\mathrm{Hg}(I I)$ Complexes. The metal complexes were prepared using metal chlorides and the Schiff base by the general method. An ethanolic solution $(40 \mathrm{~mL}$ ) of Schiff base and $\mathrm{Co}(\mathrm{II}), \mathrm{Ni}(\mathrm{II})$, $\mathrm{Cd}(\mathrm{II})$, and $\mathrm{Hg}(\mathrm{II})$ chlorides in 1:1 molar ratio and 2:1 molar ratio for $\mathrm{Cu}$ (II) complex was refluxed on water bath for about $4 \mathrm{~h}$. An aqueous solution of sodium acetate was added to the reaction mixture to adjust the $\mathrm{pH}$ to 6.0-7.0 and reflux was further continued for about an hour. The separated solid complexes were filtered off, washed thoroughly with water and then with little warm ethanol. The complexes obtained were finally dried under vacuum desiccator over fused $\mathrm{CaCl}_{2}$ (Yields: 50-55\%).

\section{Pharmacology}

3.1. Antibacterial and Antifungal Assays. The biological effects of all the synthesized compounds were undertaken for their antibacterial and antifungal properties by the agar and potato dextrose agar diffusion method, respectively $[23,24]$. The antimicrobial activities were carried out at 100,200, and $500 \mu \mathrm{g} \mathrm{mL}^{-1}$ concentrations in DMSO solvent by using bacteria E. coli (MTCC 723), S. aureus (MTCC 3160), B. subtilis (MTCC 736), P. aeruginosa (MTCC 7837) and fungi, A. flavus (MTCC 1883), A. niger (MTCC 1881), C. oxysporum (MTCC 1777), and C. albicans (MTCC 3958) by minimum inhibitory concentration (MIC) method. DMSO was used as a blank and showed no activity against any of the bacterial and fungal strains.

The bacteria were subcultured on agar medium. The petri dishes were incubated at $37^{\circ} \mathrm{C}$ for $24 \mathrm{~h}$. The fungi were subcultured on potato dextrose agar medium. The petri dishes were incubated at $37^{\circ} \mathrm{C}$ for $48 \mathrm{~h}$. The control antibacterial 
TABLE 1: Physical and analytical data of Schiff base and its complexes.

\begin{tabular}{|c|c|c|c|c|c|c|c|c|c|}
\hline Compounds & $\begin{array}{l}\text { Mol. } \\
\text { Wt }\end{array}$ & $\begin{array}{l}\text { m.p } \\
\left({ }^{\circ} \mathrm{C}\right)\end{array}$ & $\begin{array}{c}\mathrm{C} \% \\
\text { Found } \\
\text { (Calcd) }\end{array}$ & $\begin{array}{c}\mathrm{H} \% \\
\text { Found } \\
\text { (Calcd) }\end{array}$ & $\begin{array}{c}\mathrm{N} \% \\
\text { Found } \\
\text { (Calcd) }\end{array}$ & $\begin{array}{c}\text { M\% } \\
\text { Found } \\
\text { (Calcd) }\end{array}$ & $\begin{array}{l}\mathrm{Cl} \% \\
\text { Found } \\
\text { (Calcd) }\end{array}$ & $\Lambda_{\mathrm{M}}{ }^{*}$ & $\begin{array}{l}\mu_{\text {eff }} \\
(\mathrm{BM})\end{array}$ \\
\hline $\mathrm{C}_{17} \mathrm{H}_{15} \mathrm{O}_{3} \mathrm{~N}_{3}$ & 309.11 & 265 & $\begin{array}{c}65.72 \\
(65.97)\end{array}$ & $\begin{array}{l}4.66 \\
(4.83)\end{array}$ & $\begin{array}{c}13.31 \\
(13.56)\end{array}$ & - & - & - & - \\
\hline$\left[\mathrm{Co}\left(\mathrm{C}_{17} \mathrm{H}_{15} \mathrm{O}_{3} \mathrm{~N}_{3}\right) \mathrm{Cl}_{2}\right]_{n}$ & 439.04 & $>300$ & $\begin{array}{c}46.22 \\
(46.45)\end{array}$ & $\begin{array}{c}3.23 \\
(3.40)\end{array}$ & $\begin{array}{c}9.21 \\
(9.54)\end{array}$ & $\begin{array}{c}13.35 \\
(13.41)\end{array}$ & $\begin{array}{l}16.03 \\
(16.15)\end{array}$ & 8.10 & 4.82 \\
\hline$\left[\mathrm{Ni}\left(\mathrm{C}_{17} \mathrm{H}_{15} \mathrm{O}_{3} \mathrm{~N}_{3}\right) \mathrm{Cl}_{2}\right]_{n}$ & 438.80 & $>300$ & $\begin{array}{c}46.21 \\
(46.47)\end{array}$ & $\begin{array}{c}3.19 \\
(3.39)\end{array}$ & $\begin{array}{c}9.32 \\
(9.55)\end{array}$ & $\begin{array}{c}13.28 \\
(13.36)\end{array}$ & $\begin{array}{c}16.03 \\
(16.18)\end{array}$ & 6.85 & 2.85 \\
\hline$\left[\mathrm{Cu}\left(\mathrm{C}_{17} \mathrm{H}_{15} \mathrm{O}_{3} \mathrm{~N}_{3}\right)_{2} \mathrm{Cl}_{2}\right]$ & 752.72 & 285 & $\begin{array}{c}53.92 \\
(54.17)\end{array}$ & $\begin{array}{c}3.75 \\
(3.96)\end{array}$ & $\begin{array}{l}10.82 \\
(11.13)\end{array}$ & $\begin{array}{c}8.32 \\
(8.41)\end{array}$ & $\begin{array}{c}9.26 \\
(9.41)\end{array}$ & 12.40 & 1.75 \\
\hline$\left[\mathrm{Cd}\left(\mathrm{C}_{17} \mathrm{H}_{15} \mathrm{O}_{3} \mathrm{~N}_{3}\right) \mathrm{Cl}_{2}\right]$ & 492.52 & 290 & $\begin{array}{c}41.21 \\
(41.40)\end{array}$ & $\begin{array}{c}2.99 \\
(3.02)\end{array}$ & $\begin{array}{c}8.32 \\
(8.51)\end{array}$ & $\begin{array}{l}22.75 \\
(22.81)\end{array}$ & $\begin{array}{c}14.31 \\
(14.40)\end{array}$ & 15.80 & - \\
\hline$\left[\mathrm{Hg}\left(\mathrm{C}_{17} \mathrm{H}_{15} \mathrm{O}_{3} \mathrm{~N}_{3}\right) \mathrm{Cl}_{2}\right]$ & 580.70 & 298 & $\begin{array}{c}35.01 \\
(35.12)\end{array}$ & $\begin{array}{l}2.34 \\
(2.57)\end{array}$ & $\begin{array}{l}7.05 \\
(7.21)\end{array}$ & $\begin{array}{c}34.42 \\
(34.53)\end{array}$ & $\begin{array}{l}12.10 \\
(12.21)\end{array}$ & 11.40 & - \\
\hline
\end{tabular}

${ }^{*}$ Molar conductance values in $\mathrm{ohm}^{-1} \mathrm{~cm}^{2} \mathrm{~mole}^{-1}$.

(Gentamicin) and antifungal drug (Fluconazole) were also screened under similar conditions for comparison. The activity was determined by measuring the diameter of the zone showing complete inhibition.

3.2. DNA Cleavage Experiment. Preparation of culture media and DNA isolation of E. coli were done according to the literature procedure [25]. Nutrient broth $\left(10 \mathrm{~g} \mathrm{~L}^{-1}\right.$ of peptone, $5 \mathrm{gL}^{-1}$ of yeast extract and $10 \mathrm{gL}^{-1}$ of $\mathrm{NaCl}$ ) was used for culturing of $E$. coli.

3.3. Isolation of DNA. The fresh bacterial culture $(1.5 \mathrm{~mL})$ is centrifuged to obtain the pellet which is then dissolved in $0.5 \mathrm{~mL}$ of lysis buffer (100 mM tris pH 8.0, $50 \mathrm{mM}$ EDTA, $50 \mathrm{mM}$ lysozyme). To this, $0.5 \mathrm{~mL}$ of saturated phenol was added and incubated at $55^{\circ} \mathrm{C}$ for $10 \mathrm{~min}$, then centrifuged at $10,000 \mathrm{rpm}$ for $10 \mathrm{~min}$, and to the supernatant, equal volume of Chloroform: isoamyl alcohol $(24: 1)$, and 1/20th volume of $3 \mathrm{M}$ sodium acetate $(\mathrm{pH} 4.8)$ was added. Then centrifuged at $10,000 \mathrm{rpm}$ for $10 \mathrm{~min}$ and to the supernatant, 3 volumes of chilled absolute alcohol was added. The precipitated DNA was separated by centrifugation and the pellet was dried and dissolved in Tris buffer (10 mM tris $\mathrm{pH}$ 8.0) and stored in cold condition.

3.4. Agarose Gel Electrophoresis. Cleavage products were analysed by agarose gel electrophoresis method [25]. Test samples $\left(1 \mathrm{mg} \mathrm{mL}^{-1}\right)$ were prepared in DMF. The samples $(25 \mu \mathrm{g})$ were added to the isolated DNA of $E$. coli. The samples were incubated for $2 \mathrm{~h}$ at $37^{\circ} \mathrm{C}$ and then $20 \mu \mathrm{L}$ of DNA sample (mixed with bromophenol blue dye at 1:1 ratio) was loaded carefully into the electrophoresis chamber wells along with standard DNA marker containing TAE buffer $(4.84 \mathrm{~g}$ Tris base, $\mathrm{pH}$ 8.0, 0.5 M EDTA/11) and finally loaded on agarose gel. A constant $50 \mathrm{~V}$ of electricity was then passed for around $30 \mathrm{~min}$. The gel was removed and stained with $10.0 \mu \mathrm{g} \mathrm{mL}^{-1}$ ethidium bromide solution for $10-15 \mathrm{~min}$ and the bands were observed under Vilber Lourmate Gel documentation system and photographed to determine the extent of DNA cleavage. The results were then compared with the standard DNA marker.

\section{Results and Discussion}

The analytical data showed that the complexes had stoichiometry of the type $\mathrm{CuL}_{2} \mathrm{Cl}_{2}$ and $\mathrm{MLCl}_{2}$ where, $\mathrm{M}=\mathrm{Ni}(\mathrm{II})$, $\mathrm{Co}(\mathrm{II}), \mathrm{Cd}(\mathrm{II})$, and $\mathrm{Hg}(\mathrm{II})$ and $\mathrm{L}=$ Schiff base (Table 1). All the complexes were light in color, stable at room temperature, nonhygroscopic in nature, and decompose on heating. The complexes were insoluble in water and many common organic solvents but are readily soluble in DMF and DMSO. The observed molar conductance values are too low (6.85$15.80 \mathrm{ohm}^{-1} \mathrm{~cm}^{2} \mathrm{~mole}^{-1}$ ) to account for any dissociation of the complexes in DMF, indicating their nonelectrolytic nature [26].

4.1. IR Spectral Studies. A comparative interpretation of the IR spectral data of the prepared Schiff base and their $\mathrm{Co}(\mathrm{II})$, $\mathrm{Ni}(\mathrm{II}), \mathrm{Cu}(\mathrm{II}), \mathrm{Cd}(\mathrm{II})$, and $\mathrm{Hg}(\mathrm{II})$ complexes are presented in Table 2.

The IR spectrum of the free Schiff base ligand exhibited a band at $3374 \mathrm{~cm}^{-1}$ which is assigned to $v(\mathrm{OH})$ of oxime group [27]. This band remains more or less at the same position in all the complexes indicating the nonparticipation of this $\mathrm{OH}$ group in bonding. A strong band is observed at $3239 \mathrm{~cm}^{-1}$ which is assigned to $\nu(\mathrm{NH})$ stretch of the $\mathrm{CONH}$ group. The shifting of this band to a higher wave number side in all the complexes indicated the noninvolvement of " $\mathrm{N}$ " of the $\mathrm{CONH}$ group in bonding. The strong band observed at $1686 \mathrm{~cm}^{-1}$ in the free ligand was attributed to $\nu(\mathrm{C}=\mathrm{O})$ stretch of the CONH group. This band shifted to a lower wave number side in all the complexes suggesting the participation of the carbonyl oxygen in bonding with metal ions. A mediumto-strong intensity band at $1590 \mathrm{~cm}^{-1}$ in the free ligand was attributed to $\nu(\mathrm{C}=\mathrm{N})$ stretch of the azomethine group [28, 29]. Coordination of the Schiff base to the metal ions through 
TABLE 2: Spectral data of all the newly synthesized compounds.

\begin{tabular}{|c|c|}
\hline Compounds & Spectral data \\
\hline $\mathrm{C}_{17} \mathrm{H}_{15} \mathrm{O}_{3} \mathrm{~N}_{3}$ & $\begin{array}{l}\mathrm{IR}, v / \mathrm{cm}^{-1}(\mathrm{KBr}): 1569(\mathrm{C}=\mathrm{N})_{\mathrm{OX}}, 1590(\mathrm{C}=\mathrm{N}), 1686(\mathrm{C}=\mathrm{O}), 3239(\mathrm{NH}), 3374 \\
(\mathrm{OH})_{\mathrm{OX}} \\
{ }^{1} \mathrm{H} \mathrm{NMR},(\delta)\left(d_{6}-\mathrm{DMSO}\right): 2.10\left(\mathrm{~s}, 3 \mathrm{H}, \mathrm{CH}_{3}\right), 2.22\left(\mathrm{~s}, 3 \mathrm{H}, \mathrm{CH}_{3}\right), 7.60-8.50(\mathrm{~m}, 7 \mathrm{H} \\
\text { Ar), } 10.25(\mathrm{NH}), 11.70(-\mathrm{N}-\mathrm{OH}) \\
\text { GC-MS, } m / z\left(I_{r} / \%\right): 309(100 \%)\end{array}$ \\
\hline$\left[\mathrm{Co}\left(\mathrm{C}_{17} \mathrm{H}_{15} \mathrm{O}_{3} \mathrm{~N}_{3}\right) \mathrm{Cl}_{2}\right]_{n}$ & $\begin{array}{l}\mathrm{IR}, v / \mathrm{cm}^{-1}(\mathrm{KBr}): 445(\mathrm{M}-\mathrm{N}), 561(\mathrm{M}-\mathrm{O}), 1568(\mathrm{C}=\mathrm{N})_{\mathrm{OX}}, 1566(\mathrm{C}=\mathrm{N}), 1662(\mathrm{C}=\mathrm{O}) \\
3246(\mathrm{NH}), 3374(-\mathrm{N}-\mathrm{OH}) \\
\text { DART-MS, } m / z\left(I_{r} / \%\right): 439.16(40 \%) \\
\text { UV-Vis }\left(\mathrm{DMF}, \mathrm{cm}^{-1}\right): 6902,14749,16447\end{array}$ \\
\hline$\left[\mathrm{Ni}\left(\mathrm{C}_{17} \mathrm{H}_{15} \mathrm{O}_{3} \mathrm{~N}_{3}\right) \mathrm{Cl}_{2}\right]_{n}$ & $\begin{array}{l}\mathrm{IR}, v / \mathrm{cm}^{-1}(\mathrm{KBr}): 460(\mathrm{M}-\mathrm{N}), 551(\mathrm{M}-\mathrm{O}), 1569(\mathrm{C}=\mathrm{N})_{\mathrm{OX}}, 1561(\mathrm{C}=\mathrm{N}), 1651(\mathrm{C}=\mathrm{O}) \\
3249(\mathrm{NH}), 3375(-\mathrm{N}-\mathrm{OH}) \\
\text { DART-MS, } \mathrm{m} / z\left(I_{r} / \%\right): 438.96(30 \%) \\
\text { UV-Vis }\left(\mathrm{DMF}, \mathrm{cm}^{-1}\right): 7590,15151,24110\end{array}$ \\
\hline$\left[\mathrm{Cu}\left(\mathrm{C}_{17} \mathrm{H}_{15} \mathrm{O}_{3} \mathrm{~N}_{3}\right)_{2} \mathrm{Cl}_{2}\right]$ & $\begin{array}{l}\mathrm{IR}, v / \mathrm{cm}^{-1}(\mathrm{KBr}): 450(\mathrm{M}-\mathrm{N}), 553(\mathrm{M}-\mathrm{O}), 1569(\mathrm{C}=\mathrm{N})_{\mathrm{OX}}, 1552(\mathrm{C}=\mathrm{N}), 1656(\mathrm{C}=\mathrm{O}) \\
3244(\mathrm{NH}), 3374(-\mathrm{N}-\mathrm{OH}) \\
\text { DART-MS, } m / z+1\left(I_{r} / \%\right): 753.15(25 \%) \\
\text { UV-Vis }\left(\mathrm{DMF}, \mathrm{cm}^{-1}\right): 14080-16130\end{array}$ \\
\hline$\left[\mathrm{Cd}\left(\mathrm{C}_{17} \mathrm{H}_{15} \mathrm{O}_{3} \mathrm{~N}_{3}\right) \mathrm{Cl}_{2}\right]$ & $\begin{array}{l}\mathrm{IR}, v / \mathrm{cm}^{-1}(\mathrm{KBr}): 458(\mathrm{M}-\mathrm{N}), 563(\mathrm{M}-\mathrm{O}), 1568(\mathrm{C}=\mathrm{N})_{\mathrm{OX}}, 1565(\mathrm{C}=\mathrm{N}), 1644(\mathrm{C}=\mathrm{O}), \\
3252(\mathrm{NH}), 3375(-\mathrm{N}-\mathrm{OH}) \\
{ }^{1} \mathrm{H} \text { NMR, } \delta\left(d_{6}-\mathrm{DMSO}\right): 2.10\left(\mathrm{~s}, 3 \mathrm{H}, \mathrm{CH}_{3}\right), 2.22\left(\mathrm{~s}, 3 \mathrm{H}, \mathrm{CH}_{3}\right), 7.62-8.53(\mathrm{~m}, 7 \mathrm{H}, \mathrm{Ar}), \\
10.62(\mathrm{NH}), 11.70(-\mathrm{N}-\mathrm{OH}) \\
\text { DART-MS, } m / z\left(I_{r} / \%\right): 492.08(40 \%)\end{array}$ \\
\hline$\left[\mathrm{Hg}\left(\mathrm{C}_{17} \mathrm{H}_{15} \mathrm{O}_{3} \mathrm{~N}_{3}\right) \mathrm{Cl}_{2}\right]$ & $\begin{array}{l}\mathrm{IR}, v / \mathrm{cm}^{-1}(\mathrm{KBr}): 428(\mathrm{M}-\mathrm{N}), 578(\mathrm{M}-\mathrm{O}), 1568(\mathrm{C}=\mathrm{N})_{\mathrm{OX}}, 1571(\mathrm{C}=\mathrm{N}), 1647(\mathrm{C}=\mathrm{O}), \\
3251(\mathrm{NH}), 3374(-\mathrm{N}-\mathrm{OH}) \\
{ }^{1} \mathrm{H} \text { NMR, } \delta\left(d_{6} \text {-DMSO): } 2.10\left(\mathrm{~s}, 3 \mathrm{H}, \mathrm{CH}_{3}\right), 2.22\left(\mathrm{~s}, 3 \mathrm{H}, \mathrm{CH}_{3}\right), 7.63-8.53(\mathrm{~m}, 7 \mathrm{H}, \mathrm{Ar}) \text {, }\right. \\
10.89(\mathrm{NH}), 11.70(-\mathrm{N}-\mathrm{OH}) \\
\text { DART-MS, } m / z+1\left(I_{r} / \%\right): 581.28(40 \%)\end{array}$ \\
\hline
\end{tabular}

the nitrogen atom is expected to reduce electron density in the azomethine link and lower the $v(\mathrm{C}=\mathrm{N})$ stretching absorption frequency. This band shifted to a lower wave number side in all the complexes indicates the participation of the azomethine nitrogen in coordination with metal ions. The medium intensity band at $1569 \mathrm{~cm}^{-1}$ in the free ligand was attributed to $\nu(\mathrm{C}=\mathrm{N})_{\mathrm{Ox}}$ stretch of the oxime group [28]. This band remains almost unaltered in all the complexes suggesting the noninvolvement of nitrogen of oxime group in bonding. This indicates that carbonyl oxygen and azomethine nitrogen atoms are involved in coordination.

The assignments of bands in the far-infrared region have been controversial over the years, yet studies are useful as direct information about the metal-ligand coordination bond is obtained. The new weak intensity nonligand bands observed in the region $551-578 \mathrm{~cm}^{-1}$ and $428-460 \mathrm{~cm}^{-1}$ in the spectra of the complexes are assigned to stretching frequencies of $v(\mathrm{M}-\mathrm{O})$ and $v(\mathrm{M}-\mathrm{N})$ bonds, respectively. For polymeric complexes in which both terminal and bridging metalhalogen linkages are present, the $v(\mathrm{M}-\mathrm{Cl})$ stretch for the terminal halide is observed at a higher wave number side than that for the bridging halide. In the present study, we assigned the weak intensity nonligand bands to the $v(\mathrm{M}-\mathrm{Cl})$ stretch for the terminal halide at 333 and $356 \mathrm{~cm}^{-1}$ and the $v(\mathrm{M}-$ Cl) stretch for bridging at 300 and $304 \mathrm{~cm}^{-1}$ for $\mathrm{Ni}$ (II) and $\mathrm{Co}$ (II) complexes, respectively, in support of their chloridebridged polymeric structures [30, 31]. Medium intensity bands observed in the region $348-357 \mathrm{~cm}^{-1}$ were assigned to the $v(\mathrm{M}-\mathrm{Cl})$ stretch in the $\mathrm{Cu}(\mathrm{II}), \mathrm{Cd}(\mathrm{II})$, and $\mathrm{Hg}(\mathrm{II})$ complexes.

4.2. ${ }^{1} H$ NMR Spectral Studies. The ${ }^{1} \mathrm{H}$ NMR spectra of the ligand and its $\mathrm{Cd}(\mathrm{II})$ and $\mathrm{Hg}(\mathrm{II})$ complexes (Table 2) were recorded in DMSO- $d_{6}$ and are consistent with the proposed geometry. The signal at $\delta(11.70)(\mathrm{s}, 1 \mathrm{H})$ is assigned to oxime proton of $(-\mathrm{N}-\mathrm{OH}-)$ in the free ligand. This signal remains unaltered in the spectra of both the complexes confirming the noncoordination of $\mathrm{H}$ of $(-\mathrm{N}-\mathrm{OH}-)$ in bonding with metal ions. A signal at $\delta(10.25)(\mathrm{s}, 1 \mathrm{H})$ is ascribed to the $\mathrm{NH}$ proton in the free ligand and shifts downfield in the region $\delta(10.62)$ $(\mathrm{s}, 1 \mathrm{H})$ and $\delta(10.89)(\mathrm{s}, 1 \mathrm{H})$ in the $\mathrm{Cd}(\mathrm{II})$ and $\mathrm{Hg}(\mathrm{II}) \mathrm{com}-$ plexes, respectively, supporting the coordination of oxygen of $\mathrm{CONH}$ group with the metal ions. The aromatic protons at $\delta(7.60-8.50)(\mathrm{m}, 7 \mathrm{H})$ shifted downfield in the complexes. The signals at $\delta(2.10)(\mathrm{s}, 3 \mathrm{H})$ and $\delta(2.22)(\mathrm{s}, 3 \mathrm{H})$ are assigned to two methyl groups in both ligand and the complex.

4.3. Mass Spectral Studies. The GC-MS spectrum of the Schiff base showed a molecular ion peak $\mathrm{M}^{+}$at $m / z 309$, equivalent to its molecular weight. The DART mass spectra of $\mathrm{Co}$ (II), $\mathrm{Ni}(\mathrm{II})$, and $\mathrm{Cd}$ (II) complexes showed a molecular ion peak $\mathrm{M}^{+}$at $m / z$ 439.16, 438.96 and 492.08, respectively, equivalent to their molecular weights. The $\mathrm{Cu}(\mathrm{II})$ and $\mathrm{Hg}(\mathrm{II})$ complexes showed a molecular ion peaks at $\mathrm{m} / z 753.15$ and 581.28 which are one mass unit more than the molecular weight 
TABLE 3: Electronic spectral bands and ligand field parameters of the Co(II), Ni(II), and Cu(II) complexes in DMF (10 $\left.{ }^{-4} \mathrm{M}\right)$ solution.

\begin{tabular}{|c|c|c|c|c|c|c|c|c|c|}
\hline \multirow{2}{*}{ Complexes } & \multicolumn{3}{|c|}{ Transitions in $\mathrm{cm}^{-1}$} & \multirow{2}{*}{$\mathrm{Dq}\left(\mathrm{cm}^{-1}\right)$} & \multirow{2}{*}{$\mathrm{B}^{\prime}\left(\mathrm{cm}^{-1}\right)$} & \multirow{2}{*}{$\beta$} & \multirow{2}{*}{$\beta \%$} & \multirow{2}{*}{$v_{2} / v_{1}$} & \multirow{2}{*}{ LFSE (kcal) } \\
\hline & $v_{1}{ }^{*}$ & $v_{2}$ & $v_{3}$ & & & & & & \\
\hline$\left[\mathrm{Co}\left(\mathrm{C}_{17} \mathrm{H}_{15} \mathrm{O}_{3} \mathrm{~N}_{3}\right) \mathrm{Cl}_{2}\right]_{n}$ & 6902 & 14749 & 16447 & 784 & 699 & 0.720 & 28.01 & 2.136 & 13.44 \\
\hline$\left[\mathrm{Ni}\left(\mathrm{C}_{17} \mathrm{H}_{15} \mathrm{O}_{3} \mathrm{~N}_{3}\right) \mathrm{Cl}_{2}\right]_{n}$ & 7590 & 15151 & 24110 & 963 & 689 & 0.662 & 33.75 & 1.573 & 33.01 \\
\hline$\left[\mathrm{Cu}\left(\mathrm{C}_{17} \mathrm{H}_{15} \mathrm{O}_{3} \mathrm{~N}_{3}\right)_{2} \mathrm{Cl}_{2}\right]$ & \multicolumn{3}{|c|}{$14080-16130$} & 1379 & - & - & - & - & 23.64 \\
\hline
\end{tabular}

${ }^{*}$ Calculated values.

TABLE 4: Thermogravimetric data of $\mathrm{Ni}(\mathrm{II}), \mathrm{Cu}(\mathrm{II})$, and $\mathrm{Cd}(\mathrm{II})$ complexes.

\begin{tabular}{|c|c|c|c|c|c|c|}
\hline \multirow{2}{*}{$\begin{array}{l}\text { Empirical formulae of } \\
\text { the complexes }\end{array}$} & \multirow{2}{*}{$\begin{array}{l}\text { Decomposition } \\
\text { temperature }\left({ }^{\circ} \mathrm{C}\right)\end{array}$} & \multicolumn{2}{|c|}{ Weight loss (\%) } & \multicolumn{2}{|c|}{ Metal oxide (\%) } & \multirow{2}{*}{ Inference } \\
\hline & & Found & Calc. & Found & Calc. & \\
\hline \multirow{2}{*}[\mathrm{Ni}(\mathrm{C}_{17}\mathrm{H}_{15}\mathrm{O}_{3}\mathrm{N}_{3})\mathrm{Cl}_{2}]{$_{n}$} & $312-314$ & 15.59 & 15.95 & \multirow{2}{*}{13.12} & \multirow{2}{*}{13.61} & Loss of chloride molecules \\
\hline & $345-347$ & 70.09 & 70.44 & & & Loss of ligand \\
\hline \multirow{3}{*}[\mathrm{Cu}(\mathrm{C}_{17}\mathrm{H}_{15}\mathrm{O}_{3}\mathrm{N}_{3})_{2}\mathrm{Cl}_{2}]{} & $209-211$ & 8.95 & 9.29 & \multirow{3}{*}{8.14} & \multirow{3}{*}{8.43} & Loss of chloride molecules \\
\hline & $259-261$ & 22.23 & 22.61 & & & Loss of oxime moiety \\
\hline & $438-440$ & 59.10 & 59.51 & & & Loss of furan moiety \\
\hline \multirow{2}{*}[\mathrm{Cd}(\mathrm{C}_{17}\mathrm{H}_{15}\mathrm{O}_{3}\mathrm{N}_{3})\mathrm{Cl}_{2}]{} & $278-280$ & 13.85 & 14.21 & \multirow{2}{*}{22.85} & \multirow{2}{*}{23.02} & Loss of chloride molecules \\
\hline & $389-391$ & 62.32 & 62.76 & & & Loss of ligand \\
\hline
\end{tabular}

of the complexes, supporting the suggested structure for the complexes.

4.4. Electronic Spectral Studies. The electronic absorption spectra of the $\mathrm{Co}(\mathrm{II}), \mathrm{Ni}(\mathrm{II})$, and $\mathrm{Cu}(\mathrm{II})$ complexes were recorded in freshly prepared DMF solution $\left(10^{-4} \mathrm{M}\right)$ at room temperature. The spectral data and ligand field parameters are presented in Tables 2 and 3, respectively.

The electronic spectrum of the Co(II) complex displayed bands at 14749 and $16447 \mathrm{~cm}^{-1}$. These two bands are assignable to ${ }^{4} \mathrm{~T}_{1 \mathrm{~g}}(\mathrm{~F}) \rightarrow{ }^{4} \mathrm{~A}_{2 \mathrm{~g}}(\mathrm{~F})\left(\nu_{2}\right)$ and ${ }^{4} \mathrm{~T}_{1 \mathrm{~g}}(\mathrm{~F}) \rightarrow{ }^{4} \mathrm{~T}_{2 \mathrm{~g}}(\mathrm{P})\left(\nu_{3}\right)$ transitions, respectively, in an octahedral environment [32]. The lowest band, $v_{1}$, could not be observed due to the limited range of the instrument used but could be calculated using the band fitting procedure suggested by Underhill and Billing [33].

The Ni(II) complex exhibited two absorption bands, at 15151 and $24110 \mathrm{~cm}^{-1}$ assignable to ${ }^{3} \mathrm{~A}_{2 \mathrm{~g}}(\mathrm{~F}) \rightarrow{ }^{3} \mathrm{~T}_{1 \mathrm{~g}}(\mathrm{~F})\left(\nu_{2}\right)$ and ${ }^{3} \mathrm{~A}_{2 \mathrm{~g}}(\mathrm{~F}) \rightarrow{ }^{3} \mathrm{~T}_{1 \mathrm{~g}}(\mathrm{P})\left(\nu_{3}\right)$ transitions, respectively, in an octahedral environment. The band $\nu_{1}$ was calculated by using a band fitting procedure [33].

The light green colored $\mathrm{Cu}(\mathrm{II})$ complex exhibited a single broad asymmetric band in the region $14080-16130 \mathrm{~cm}^{-1}$. The broadness of the band indicates the three transitions ${ }^{2} \mathrm{~B}_{1 \mathrm{~g}} \rightarrow$ ${ }^{2} \mathrm{~A}_{1 \mathrm{~g}}\left(\nu_{1}\right),{ }^{2} \mathrm{~B}_{1 \mathrm{~g}} \rightarrow{ }^{2} \mathrm{~B}_{2 \mathrm{~g}}\left(v_{2}\right)$, and ${ }^{2} \mathrm{~B}_{1 \mathrm{~g}} \rightarrow{ }^{2} \mathrm{E}_{\mathrm{g}}\left(v_{3}\right)$, which are of similar energy and gives rise to only one broad absorption band. The broadness of the band may be due to dynamic Jahn-Teller distortion. All of these data suggested a distorted octahedral geometry around the $\mathrm{Cu}$ (II) ion. The octahedral geometry was further supported by the values of ligand field parameters, such as the Racah interelectronic repulsion parameter $\left(\mathrm{B}^{\prime}\right)$, ligand field splitting energy $(10 \mathrm{Dq})$, covalency factor $(\beta)$, and ligand field stabilization energy (LFSE) [34].

The $\mathrm{B}^{\prime}$ values for the complexes were lower than the free ion values, which is an indication of the orbital overlap and delocalisation of $\mathrm{d}$-orbitals. The $\beta$ value for the $\mathrm{Ni}$ (II) complex was less than that of the Co(II) complex, indicating the greater covalency of the M-L bond [35].

4.5. Thermal Decomposition Studies. Thermal stabilities were investigated for some of the complexes. The solid complexes were stable at room temperature and decompose gradually with the formation of respective metal oxides above $500^{\circ} \mathrm{C}$. The nature of proposed chemical change with temperature and the percent of metal oxide obtained are given in Table 4. The spectrum of representative $\left[\mathrm{Ni}\left(\mathrm{C}_{17} \mathrm{H}_{15} \mathrm{O}_{3} \mathrm{~N}_{3}\right) \mathrm{Cl}_{2}\right]_{n}$ complex presented in Figure 1 decomposes into two steps. The first step shows an endothermic peak in the temperature range of $312-314^{\circ} \mathrm{C}$, which indicates the loss of two chloride molecules (Found: $15.59 \%$, Calc: $15.95 \%$ ). The weight loss in the range $345-347^{\circ} \mathrm{C}$ corresponds to the decomposition of the ligand (Found: $70.09 \%$, Calc: $70.44 \%$ ), further leaving behind the metal oxide residue.

In the $\left[\mathrm{Cu}\left(\mathrm{C}_{17} \mathrm{H}_{15} \mathrm{O}_{3} \mathrm{~N}_{3}\right)_{2} \mathrm{Cl}_{2}\right]$ complex, the spectrum shows three decomposition peaks, the first decomposition peak in the temperature range $209-211^{\circ} \mathrm{C}$ corresponds to the loss of two chloride molecules, the second decomposition peak in the temperature range $259-261^{\circ} \mathrm{C}$ corresponds to loss of oxime moiety, and the third decomposition peak at 438$440^{\circ} \mathrm{C}$ range corresponds to loss of furan moiety.

In the case of $\left[\mathrm{Cd}\left(\mathrm{C}_{17} \mathrm{H}_{15} \mathrm{O}_{3} \mathrm{~N}_{3}\right) \mathrm{Cl}_{2}\right]$ complex, the weight losses in the temperature range $278-280^{\circ} \mathrm{C}$ and $389-391^{\circ} \mathrm{C}$ corresponds to loss of chloride and ligand molecules. The metal content in all the complexes as done by elemental analysis agrees well with the thermal studies. 


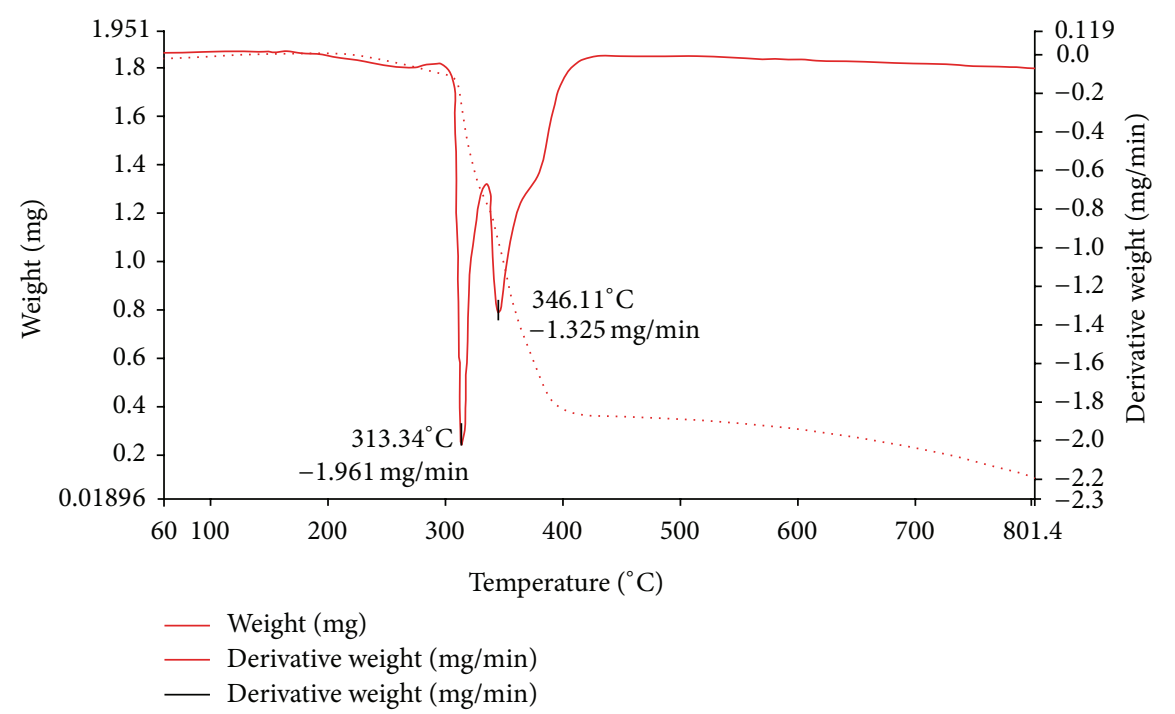

Figure 1: TG-DTA plot of Ni(II) complex.

4.6. ESR Spectrum of the Cu(II) Complex. This study gives information about the hyperfine and superhyperfine structures to elucidate the geometry and the degree of covalency of the metal-ligand bonds. The ESR spectrum of the $\mathrm{Cu}$ (II) complex in a polycrystalline state was recorded at room temperature show $\mathrm{g}_{\|}\left[\mathrm{g}_{\|}(1)+\mathrm{g}_{\|}(2)=2.212+2.122\right]$ and $\mathrm{g}_{\perp}$ values of 2.167 and 2.038 , respectively. The $g_{\text {av }}$ was calculated to be 2.08. The spectrum showed asymmetric bands with $g_{\|}>g_{\perp}>$ 2.00277, indicating that the unpaired electrons lay predominantly in the $\mathrm{d}_{\mathrm{x}^{2}-\mathrm{y}^{2}}$ orbital with possible mixing of $\mathrm{d}_{z^{2}}$ because of low symmetry [36]. The axial symmetry parameter " $G$ " was determined as $G=\left(g_{\|}-2.00277\right) /\left(g_{\perp}-2.00277\right)=4.66$, which is more than 4 suggesting the absence of exchange coupling between $\mathrm{Cu}(\mathrm{II})$ centers in the solid state [37]. Thus, the results suggest that $\mathrm{Cu}(\mathrm{II})$ complex possesses distorted octahedral geometry [38].

4.7. Magnetic Studies. The magnetic moments of Co(II), $\mathrm{Ni}$ (II) and $\mathrm{Cu}$ (II) complexes were obtained at room temperature. The magnetic moment values are listed in Table 1. Under this study, the Co(II) complex exhibited the magnetic moment value of $4.82 \mathrm{BM}$ indicating an octahedral geometry [39]. The magnetic moment observed for $\mathrm{Ni}(\mathrm{II})$ complex lies in the range of $2.8-3.5 \mathrm{BM}$ showing a value of 2.85 which is consistent with the octahedral stereochemistry of the complex [40]. The $\mathrm{Cu}(\mathrm{II})$ complex exhibited a magnetic moment value of $1.75 \mathrm{BM}$, slightly higher than the spin-only value of $1.73 \mathrm{BM}$ expected for one unpaired electron suggesting the possibility of an octahedral geometry [41].

4.8. Redox Study. Electron transfer plays a vital role in governing the pathway of chemical reactions. Cyclic voltammetry is the most versatile electroanalytical technique for the study of electroactive species. The cyclic voltammogram of the copper complex (Figure 2) in DMF at scan rate of $0.1 \mathrm{~V} \mathrm{~s}^{-1}$ using a glassy carbon working electrode shows a welldefined redox process corresponding to the formation of

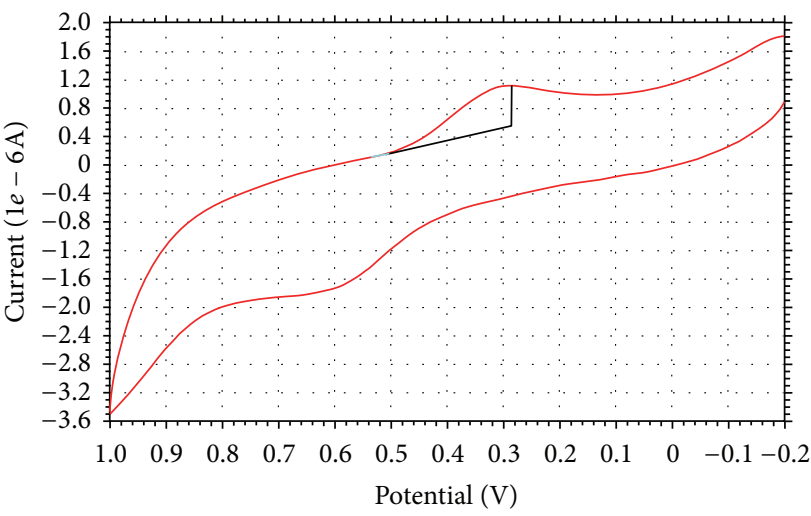

FIgure 2: Cyclic voltammogram of $\mathrm{Cu}(\mathrm{II})$ complex.

$\mathrm{Cu}(\mathrm{II}) / \mathrm{Cu}(\mathrm{I})$ couple at $\mathrm{E}_{\mathrm{pa}}=0.60 \mathrm{~V}$ versus $\mathrm{Ag} / \mathrm{AgCl}$ and $\mathrm{E}_{\mathrm{pc}}=0.28 \mathrm{~V}$. This couple is found to be quasi-reversible with $\Delta \mathrm{Ep}=0.32 \mathrm{~V}$ and the ratio of anodic to cathodic peak currents corresponding to a simple one-electron process. The values of $\mathrm{E}_{\mathrm{pa}}$ and $\mathrm{E}_{\mathrm{pc}}$ of the $\mathrm{Cu}(\mathrm{II}) / \mathrm{Cu}(\mathrm{I})$ couple were little affected in the scan rate variation studies, suggesting no change in the quasi reversibility. The peak current increases with increasing square root of the scan rate, establishing diffusion controlled electrode process [42]. From the value of peak separation, $\Delta \mathrm{Ep}$, and the peak current ratio we can suggest that the electrode processes are consistent with the quasi reversibility [43] of the $\mathrm{Cu}(\mathrm{II}) / \mathrm{Cu}(\mathrm{I})$ couple [44].

\section{Pharmacology Results}

5.1. Antibacterial and Antifungal Analyses. The Schiff base and its complexes used in the present study were screened against Escherichia coli, Staphylococcus aureus, Bacillus subtilis, Pseudomonas aeruginosa bacteria and Aspergillus niger, Aspergillus flavus, Cladosporium oxysporum, and Candida albicans fungi. 
TABLE 5: Antimicrobial activity results of the Schiff base and its metal complexes (MIC).

\begin{tabular}{|c|c|c|c|c|c|c|c|c|c|}
\hline \multirow{2}{*}{ Schiff base/complexes } & \multirow{2}{*}{$\begin{array}{c}\text { Conc. } \\
\left(\mu \mathrm{g} \mathrm{mL}^{-1}\right)\end{array}$} & \multicolumn{8}{|c|}{ Zone of inhibition against bacteria and fungi (mm) } \\
\hline & & E. coli & S. aureus & B. subtilis & P. aeruginosa & A. niger & A. flavus & C. oxysporum & C. albicans \\
\hline \multirow{3}{*}{$\mathrm{C}_{17} \mathrm{H}_{15} \mathrm{O}_{3} \mathrm{~N}_{3}$} & 100 & 05 & 05 & - & 04 & 07 & 07 & 06 & - \\
\hline & 200 & 12 & 13 & 09 & 10 & 13 & 14 & 12 & 08 \\
\hline & 500 & 14 & 15 & 11 & 13 & 15 & 16 & 13 & 14 \\
\hline \multirow{3}{*}[\mathrm{Co}(\mathrm{C}_{17}\mathrm{H}_{15}\mathrm{O}_{3}\mathrm{N}_{3})\mathrm{Cl}_{2}]{$_{n}$} & 100 & 06 & 07 & 04 & 05 & 09 & 08 & 07 & 06 \\
\hline & 200 & 14 & 14 & 10 & 12 & 14 & 16 & 13 & 09 \\
\hline & 500 & 16 & 16 & 12 & 14 & 16 & 18 & 15 & 15 \\
\hline \multirow{3}{*}[\mathrm{Ni}(\mathrm{C}_{17}\mathrm{H}_{15}\mathrm{O}_{3}\mathrm{N}_{3})\mathrm{Cl}_{2}]{$_{n}$} & 100 & 07 & 08 & 04 & 06 & 09 & 10 & 08 & 07 \\
\hline & 200 & 14 & 15 & 10 & 13 & 15 & 16 & 14 & 16 \\
\hline & 500 & 15 & 16 & 12 & 13 & 16 & 19 & 15 & 15 \\
\hline \multirow{3}{*}[\mathrm{Cu}(\mathrm{C}_{17}\mathrm{H}_{15}\mathrm{O}_{3}\mathrm{N}_{3})_{2}\mathrm{Cl}_{2}]{} & 100 & 07 & 07 & 05 & 06 & 10 & 11 & 09 & 06 \\
\hline & 200 & 15 & 17 & 13 & 15 & 16 & 17 & 15 & 17 \\
\hline & 500 & 16 & 18 & 14 & 17 & 17 & 19 & 15 & 16 \\
\hline \multirow{3}{*}[\mathrm{Cd}(\mathrm{C}_{17}\mathrm{H}_{15}\mathrm{O}_{3}\mathrm{N}_{3})\mathrm{Cl}_{2}]{} & 100 & 11 & 13 & 08 & 10 & 18 & 19 & 17 & 16 \\
\hline & 200 & 19 & 18 & 15 & 16 & 20 & 20 & 19 & 18 \\
\hline & 500 & 22 & 21 & 18 & 19 & 21 & 22 & 20 & 22 \\
\hline \multirow{3}{*}[\mathrm{Hg}(\mathrm{C}_{17}\mathrm{H}_{15}\mathrm{O}_{3}\mathrm{N}_{3})\mathrm{Cl}_{2}]{} & 100 & 11 & 12 & 09 & 11 & 18 & 20 & 17 & 19 \\
\hline & 200 & 20 & 20 & 16 & 17 & 21 & 22 & 18 & 19 \\
\hline & 500 & 23 & 21 & 17 & 20 & 25 & 26 & 24 & 22 \\
\hline Gentamicin & 500 & 29 & 28 & 25 & 26 & - & - & - & - \\
\hline Fluconazole & 500 & - & - & - & & 30 & 31 & 30 & 29 \\
\hline
\end{tabular}

Note: less than $12 \mathrm{~mm}$ : inactive; $12-16 \mathrm{~mm}$ : moderately active; above $18 \mathrm{~mm}$ : highly active.

The microbial screening results presented in Table 5 reveal that the Schiff base is active and its metal complexes showed increased antibacterial and antifungal activity. The $\mathrm{Co}(\mathrm{II}), \mathrm{Ni}(\mathrm{II})$, and $\mathrm{Cu}(\mathrm{II})$ complexes exhibited good antibacterial activity against Escherichia coli and Staphylococcus aureus whereas Bacillus subtilis and Pseudomonas aeruginosa have shown moderate activity. In the case of antifungal activity all the tested complexes have shown good activity against both Aspergillus niger and Aspergillus flavus fungi and moderate activity against Cladosporium oxysporum and Candida albicans. The $\mathrm{Cd}(\mathrm{II})$ and $\mathrm{Hg}$ (II) complexes have shown higher activity against both the bacterial and fungal strains compared to the Schiff base ligand and $\mathrm{Co}(\mathrm{II}), \mathrm{Ni}(\mathrm{II})$, and $\mathrm{Cu}$ (II) complexes, however, are less active than the standard drugs. Generally, it is claimed that the enhancement in the activity may be due to the fact that the ligand possess $\mathrm{C}=\mathrm{N}$ bond. The ligands with nitrogen and oxygen donor atoms inhibit enzyme activity, since the enzymes which require these groups for their activity appear to be especially more susceptible to deactivation by metal ions on coordination. The activity of the metal chelates can be explained on the basis of Overtone's concept and Tweedy's chelation theory [45]. The enhanced activity of the metal complexes may be retained to the increased lipophilic nature of the complexes which arose from the chelation. It was also noted that the toxicity of the metal complexes increases on increasing the metal ion concentration. In general, metal complexes are more active than the ligands because metal complexes may serve

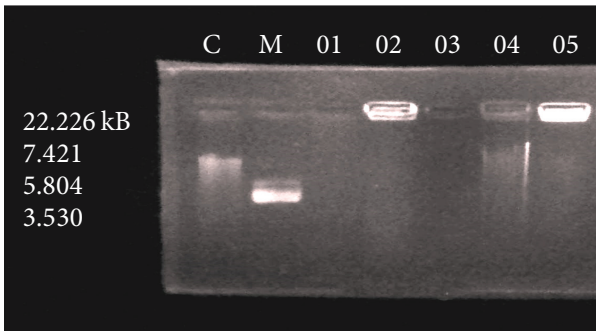

Figure 3: DNA cleavage activity studies of $\mathrm{Cu}(\mathrm{II}), \mathrm{Ni}(\mathrm{II}), \mathrm{Co}(\mathrm{II})$, $\mathrm{Cd}(\mathrm{II})$, and $\mathrm{Hg}(\mathrm{II})$ (lanes-O1, O2, O3, O4, and O5) complexes, respectively. M: standard molecular weight Marker; C: control DNA.

as a vehicle for activation of ligands as the principle cytotoxic species [46]. However, from the data, it is inferred that the newly synthesized compounds are effective fungicides than bactericides.

5.2. Electrophoretic Analysis. The $\mathrm{Co}(\mathrm{II}), \mathrm{Ni}(\mathrm{II}), \mathrm{Cu}(\mathrm{II})$, $\mathrm{Cd}(\mathrm{II})$, and $\mathrm{Hg}$ (II) complexes were monitored for their DNA cleavage ability by agarose gel electrophoresis method against DNA of E. coli at $100 \mu \mathrm{g} \mathrm{mL}^{-1}$ (Figure 3).

The cleavage efficiency of the complexes compared to that of the control is due to their efficient DNA-binding ability. DNA-binding studies helps in the rational designing and construction of new and more efficient drugs targeted to DNA [47]. A comparative study of gel electrophoresis analysis 


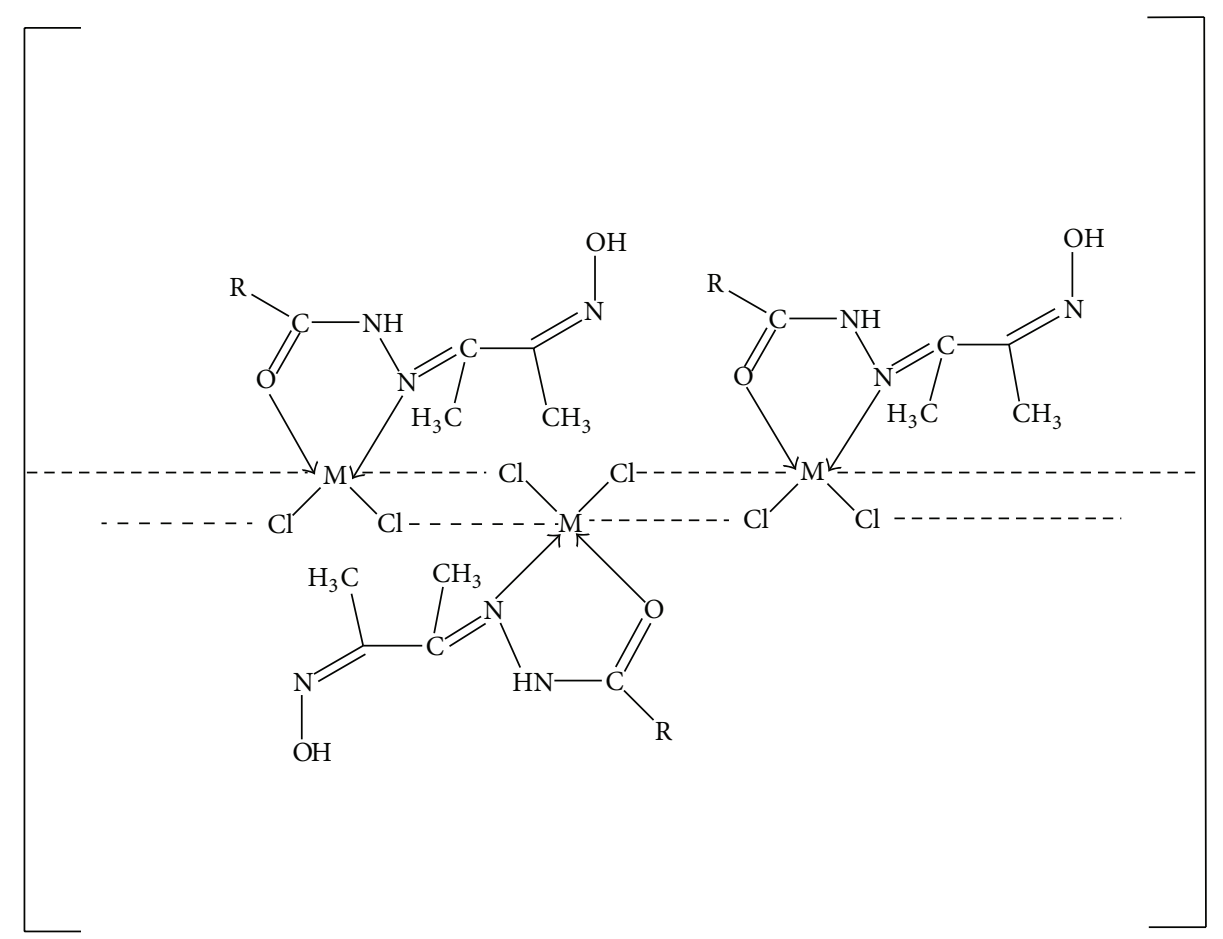

Where $\mathrm{M}=\mathrm{Co}(\mathrm{II})$ or $\mathrm{Ni}(\mathrm{II})$ ions

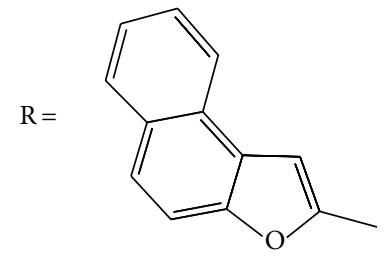

FIgure 4: Suggested structure for $\left[\mathrm{Co}\left(\mathrm{C}_{17} \mathrm{H}_{15} \mathrm{O}_{3} \mathrm{~N}_{3}\right) \mathrm{Cl}_{2}\right]_{n}$ or $\left[\mathrm{Ni}\left(\mathrm{C}_{17} \mathrm{H}_{15} \mathrm{O}_{3} \mathrm{~N}_{3}\right) \mathrm{Cl}_{2}\right]_{n}$ complexes.

of the control DNA with the metal complexes revealed that the control DNA does not show any cleavage whereas $\mathrm{Cu}$ (II) and $\mathrm{Co}$ (II) complexes (lanes $\mathrm{O} 1$ and O3) have shown complete cleavage of DNA, while the $\mathrm{Ni}(\mathrm{II}), \mathrm{Cd}(\mathrm{II})$, and $\mathrm{Hg}$ (II) complexes (lanes O2, O4, and O5) have exhibited partial cleavage activity, which is evidenced by diminishing in intensity of the lanes. However, the nature of reactive intermediates involved in the DNA cleavage by the complexes is not clear. The results indicated the important role of metal ions in isolated DNA cleavage reactions. As the complexes were observed to cleave the DNA, it can be concluded that, the compounds inhibit the growth of the pathogenic organism by cleaving the genome [48]. The different DNA cleavage ability of the complexes may be due to the different binding affinity of the complexes to the DNA molecule.

\section{Conclusions}

In this research article, we have synthesized a new Schiff base ligand and its metal complexes. The formation of the compounds has been confirmed by the analytical data, IR, electronic, mass, ${ }^{1} \mathrm{H}$ NMR, thermal and ESR spectral studies, magnetic susceptibility, electrochemical, and molar conductance data. The above studies reveal that the Schiff base acts as neutral bidentate coordinating through azomethine nitrogen and carbonyl oxygen atoms to the metal ions. The electrochemical behavior of $\mathrm{Cu}(\mathrm{II})$ complex exhibited the one electron transfer quasi-reversible redox couple. The antimicrobial activity results displayed that $\mathrm{Cd}(\mathrm{II})$ and $\mathrm{Hg}(\mathrm{II})$ complexes exhibit higher activity compared to $\mathrm{Co}(\mathrm{II}), \mathrm{Ni}(\mathrm{II})$, and $\mathrm{Cu}(\mathrm{II})$ complexes. It is well noticed that the synthesized metal complexes exhibited more inhibitory effects than the parent Schiff base ligand as the efficacy of the organic compound is positively modified upon coordination with the metal ions. The gel electrophoresis experiment depicted that $\mathrm{Cu}$ (II) and $\mathrm{Co}$ (II) complexes cleaved the DNA molecule completely. Thus, the present study gives valuable information to the bioorganic/inorganic chemists and contributes better knowledge to the field of bioinorganic chemistry. On the basis of their physicochemical data, we propose polymeric octahedral geometry for $\mathrm{Co}(\mathrm{II})$ and $\mathrm{Ni}(\mathrm{II})$ complexes (Figure 4), dimeric octahedral for $\mathrm{Cu}(\mathrm{II})$ complex (Figure 5), and tetrahedral structures to $\mathrm{Cd}(\mathrm{II})$ and $\mathrm{Hg}$ (II) complexes (Figure 6). 


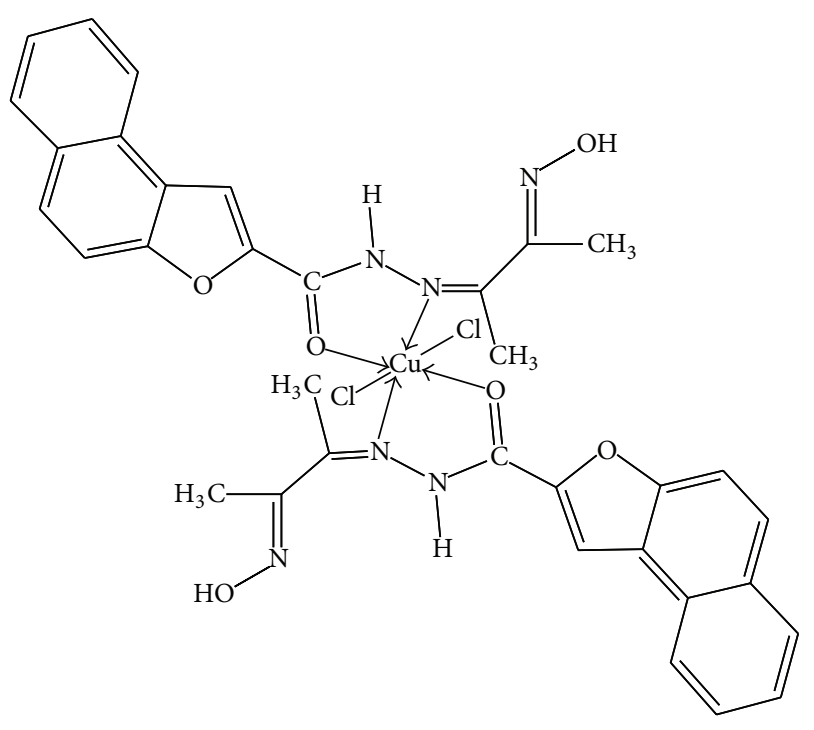

Figure 5: Suggested structure for $\left[\mathrm{Cu}\left(\mathrm{C}_{17} \mathrm{H}_{15} \mathrm{O}_{3} \mathrm{~N}_{3}\right)_{2} \mathrm{Cl}_{2}\right]$ complex.

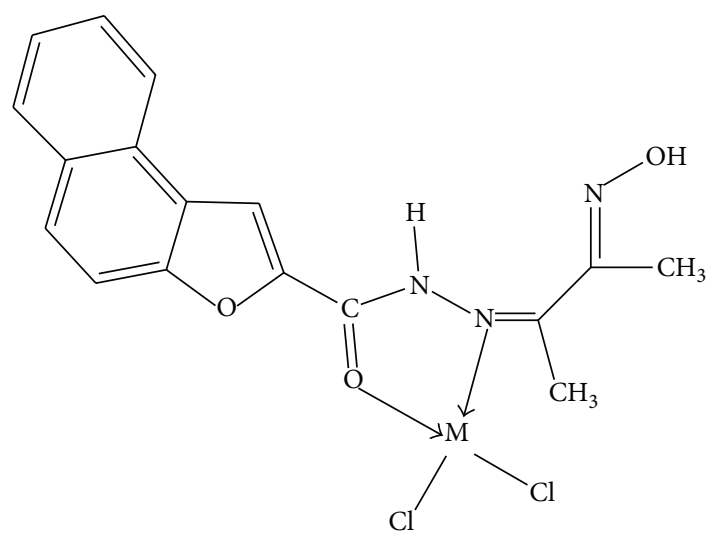

Where $\mathrm{M}=\mathrm{Cd}(\mathrm{II})$ or $\mathrm{Hg}(\mathrm{II})$ ions

Figure 6: Suggested structure for $\left[\mathrm{Cd}\left(\mathrm{C}_{17} \mathrm{H}_{15} \mathrm{O}_{3} \mathrm{~N}_{3}\right) \mathrm{Cl}_{2}\right]$ or $\left[\mathrm{Hg}\left(\mathrm{C}_{17} \mathrm{H}_{15} \mathrm{O}_{3} \mathrm{~N}_{3}\right) \mathrm{Cl}_{2}\right]$ complexes.

\section{Conflict of Interests}

The authors declare that there is no conflict of interests regarding the publication of this paper.

\section{Acknowledgments}

The authors are thankful to the Chairman, Department of Chemistry, Gulbarga University, Gulbarga, for the facilities. R. B. Sumathi is thankful to UGC New Delhi for the Grant of Research fellowship in Science for meritorious students under the RFSMS scheme. The authors are also thankful to SAIF, CDRI Lucknow, IISC Bangalore, IIT Bombay, and STIC Cochin for providing spectral data.

\section{References}

[1] J. P. Naskar, C. Biswas, L. Lu, and M. Zhu, "Synthesis, crystal structure and spectroscopic properties of an oximato bridged $\mathrm{cu}(\mathrm{II})$ dimer," Journal of Chemical Crystallography, vol. 41, no. 4, pp. 502-507, 2011.

[2] A. G. Smith, P. A. Tasker, and D. J. White, "The structures of phenolic oximes and their complexes," Coordination Chemistry Reviews, vol. 241, no. 1-2, pp. 61-85, 2003.

[3] K. Narasaka, "Synthesis of azaheterocycles from oxime derivatives," Pure and Applied Chemistry, vol. 75, no. 1, pp. 19-28, 2003.

[4] E. Manessi-Zoupa, K. F. Konidaris, C. P. Raptopoulou, V. Psycharis, S. P. Perlepes, and T. C. Stamatatos, "Use of the 2-pyridinealdoxime/n,n/-donor ligand combination in cobalt(III) chemistry: synthesis and characterization of two cationic mononuclear cobalt(III) complexes," Bioinorganic Chemistry and Applications, vol. 2010, Article ID 159656, 7 pages, 2010.

[5] M. V. Barybin, P. L. Diaconescu, and C. C. Cummins, "Coordination chemistry of a chelating amidoximato ligand," Inorganic Chemistry, vol. 40, no. 12, pp. 2892-2897, 2001.

[6] N. Chowdhury, S. Dutta, S. Dasgupta, N. D. P. Singh, M. Baidya, and S. K. Ghosh, "Synthesis, photophysical, photochemical, DNA cleavage/binding and cytotoxic properties of pyrine oxime ester conjugates," Photochemical and Photobiological Sciences, vol. 11, no. 7, pp. 1239-1250, 2012.

[7] A. Braga de Oliveira and G. G. De Oliveira, "Laevigatin, a sesquiterpenoid furan from Eupatorium laevigatum Lam," Tetrahedron Letters, vol. 30, pp. 2653-2654, 1978.

[8] D. H. Miles, D. Lho, A. A. De La Cruz, E. D. Gomez, J. A. Weeks, and J. L. Atwood, "Toxicants from mangrove plants. 3. Heritol, a novel ichthyotoxin from the mangrove plant Heritiera littoralis," Journal of Organic Chemistry, vol. 52, no. 13, pp. 2930-2932, 1987.

[9] P. K. Zubaidha, S. P. Chavan, U. S. Racherla, and N. R. Ayyangar, "Synthesis of ( \pm ) heritol," Tetrahedron, vol. 47, no. 30, pp. 5759$5768,1991$.

[10] K. Ishiguro, Y. Ohira, and H. Oku, "Antipruritic dinaphthofuran-7,12-dione derivatives from the pericarp of Impatiens balsamina," Journal of Natural Products, vol. 61, no. 9, pp. 1126-1129, 1998.

[11] C. Kirilmiş, M. Koca, S. Servi, and S. Gür, "Synthesis and antimicrobial activity of dinaphtho[2,1-b]furan-2-yl-methanone and their oxime derivatives," Turkish Journal of Chemistry, vol. 33, no. 3, pp. 375-384, 2009.

[12] B. Padmashali, V. P. Vaidya, K. M. Mahadevan, and K. P. Latha, "Synthesis of novel angularly fused pentacyclic heterocycles of pharmacological interest," Indian Journal of Chemistry B, vol. 44, no. 7, pp. 1446-1451, 2005.

[13] P. K. Sharma, R. N. Khanna, B. K. Rohatgi, and R. H. Thomson, "Tecomaquinone-III: a new quinone from Tabebuia pentaphylla," Phytochemistry, vol. 27, no. 2, pp. 632-633, 1988.

[14] G. K. Nagaraja, G. K. Prakash, M. N. Kumaraswamy, V. P. Vaidya, and K. M. Mahadevan, "Synthesis of novel nitrogen containing naphtho[2,1-b] furan derivatives and investigation of their anti microbial activities," Arkivoc, vol. 105, pp. 160-168, 2006.

[15] M. N. Kumaraswamy and V. P. Vaidya, "Novel method for the synthesis of symmetrical and asymmetrical azines involving naphtho [2,1-b] furan and their antimicrobial activity," Indian Journal of Heterocyclic Chemistry, vol. 14, no. 3, pp. 193-196, 2005. 
[16] V. P. Vaidya, H. M. Vagdevi, K. M. Mahadevan, and C. S. Shreedhara, "Synthesis of naphtho[2,1-b]furo[3,2-e]-1,4-diazepin-2ones and naphtho[2,1-b]furo[3,2-e]-1,3,4-triazepin-2-ones of pharmacological interest," Indian Journal of Chemistry B, vol. 43, no. 7, pp. 1537-1543, 2004.

[17] Z. H. Chohan and C. T. Supuran, "Structure and biological properties of first row d-transition metal complexes with $\mathrm{N}$ substituted sulfonamides," Journal of Enzyme Inhibition and Medicinal Chemistry, vol. 23, no. 2, pp. 240-251, 2008.

[18] E. Canpolat and M. Kaya, "Studies on mononuclear chelates derived from substituted Schiff-base ligands (part 2): synthesis and characterization of a new 5-bromosalicyliden-p- aminoacetophenoneoxime and its complexes with $\mathrm{Co}(\mathrm{II}), \mathrm{Ni}(\mathrm{II}), \mathrm{Cu}(\mathrm{II})$ and $\mathrm{Zn}(\mathrm{II})$," Journal of Coordination Chemistry, vol. 57, no. 14, pp. 1217-1223, 2004.

[19] R. Ramesh and M. Sivagamasundari, "Synthesis, spectral, and antifungal activity of $\mathrm{Ru}(\mathrm{II})$ mixed-ligand complexes," Synthesis and Reactivity in Inorganic and Metal-Organic Chemistry, vol. 33, no. 5, pp. 899-910, 2003.

[20] N. Raman, S. J. Raja, J. Joseph, and J. D. Raja, "Molecular designing, structural elucidation, and comparison of the cleavage ability of oxovanadium(IV) Schiff base complexes," Russian Journal of Coordination Chemistry, vol. 33, no. 1, pp. 7-11, 2007.

[21] M. B. Halli and R. B. Sumathi, "Synthesis, spectroscopic, antimicrobial and DNA cleavage studies of new $\mathrm{Co}(\mathrm{II}), \mathrm{Ni}(\mathrm{II}), \mathrm{Cu}(\mathrm{II})$, $\mathrm{Cd}(\mathrm{II}), \mathrm{Zn}(\mathrm{II})$ and $\mathrm{Hg}(\mathrm{II})$ complexes with naphthofuran-2carbohydrazide Schiff base," Journal of Molecular Structure, vol. 1022, pp. 130-138, 2012.

[22] A. I. Vogel, A Text Book of Quantitative Inorganic Analysis, Longman ELBS, London, UK, 3rd edition, 1968.

[23] E. J. Threlfall, I. S. T. Fisher, L. R. Ward, H. Tschäpe, and P. Gerner-Smidt, "Harmonization of antibiotic susceptibility testing for Salmonella: results of a study by 18 national reference laboratories within the European Union-funded Enter-net group," Microbial Drug Resistance, vol. 5, no. 3, pp. 195-200, 1999.

[24] R. D. Walker, "Antimicrobial susceptibility testing and interpretation of results," in Antimicrobial Therapy in Veterinary Medicine, J. F. Prescott, J. D. Baggot, and R. D. Walker, Eds., pp. 1226, Iowa State University Press, Ames, Iowa, USA, 2000.

[25] J. Sambrook, E. F. Fritsch, and T. Miniatis, Molecular Cloning, A Laboratory Manual, Cold Spring Harbor Laboratory, Cold Spring Harbor, NY, USA, 2nd edition, 1989.

[26] W. J. Geary, "The use of conductivity measurements in organic solvents for the characterisation of coordination compounds," Coordination Chemistry Reviews, vol. 7, no. 1, pp. 81-122, 1971.

[27] M. Kurtoǧlu, F. Purtaş, and S. Toroǧlu, "A new vic-dioxime ligand containing two azo substituents and its mononuclear nickel(II), cobalt(II), and copper(II) complexes; Synthesis, characterization, spectroscopic and biological studies," Transition Metal Chemistry, vol. 33, no. 6, pp. 705-710, 2008.

[28] B. Guhathakurta, C. Biswas, J. P. Naskar, L. Lu, and M. Zhu, "Synthesis and crystal structure of a complex of palladium(ii) with 2-hydroxyimino-3-(2-hydrazonopyridyl)-butane," Journal of Chemical Crystallography, vol. 41, no. 9, pp. 1355-1359, 2011.

[29] A. Sengul, H. Ağaç, B. Çoban, and E. Eroglu, "Structural studies of complex compounds of 6,6'-diacetyl-2,2'-bipyridine dioxime with copper(I/II), platinum(II), and palladium(II) metal ions," Turkish Journal of Chemistry, vol. 35, no. 1, pp. 25-36, 2011.

[30] G. Devoto, M. Massacesi, G. Ponticelli, and C. Preti, "3,5diphenylisoxazole as ligand. Complexes of cobalt(II), nickel(II) and copper(II)," Journal of Inorganic and Nuclear Chemistry, vol. 39, no. 2, pp. 271-274, 1977.

[31] D. N. Satyanarayana, Vibrational Spectroscopy, vol. 407, New Age International, New Delhi, India, 2004.

[32] A. B. P. Lever, Inorganic Electronic Spectroscopy, Elsevier, New York, NY, USA, 1984.

[33] A. E. Underhill and D. E. Billing, "Calculations of the racah parameter B for nickel (II) and cobalt (II) compounds," Nature, vol. 210, no. 5038, pp. 834-835, 1966.

[34] D. N. Satyanarayana, Electronic Absorption Spectroscopy and Related Techniques, University Press India Limited, New Delhi, India, 2001.

[35] K. Shivakumar, S. Shashidhar, P. Vithal Reddy, and M. B. Halli, "Synthesis, spectral characterization and biological activity of benzofuran Schiff bases with $\mathrm{Co}(\mathrm{II}), \mathrm{Ni}(\mathrm{II}), \mathrm{Cu}(\mathrm{II}), \mathrm{Zn}$ (II), $\mathrm{Cd}(\mathrm{II})$ and $\mathrm{Hg}$ (II) complexes," Journal of Coordination Chemistry, vol. 61, no. 14, pp. 2274-2287, 2008.

[36] R. Neiman and D. Kivelson, "ESR line shapes in glasses of copper complexes," The Journal of Chemical Physics, vol. 35, no. 1, pp. 149-155, 1961.

[37] B. J. Hathaway and D. E. Billing, “The electronic properties and stereochemistry of mono-nuclear complexes of the copper(II) ion," Coordination Chemistry Reviews, vol. 5, no. 2, pp. 143-207, 1970.

[38] N. Raman, A. Sakthivel, and R. Jeyamurugan, "Synthesis, structural characterization, antimicrobial, DNA-binding, and photoinduced DNA cleavage activity of some bio-sensitive Schiff base copper(II) complexes," Journal of Coordination Chemistry, vol. 63, no. 24, pp. 4380-4397, 2010.

[39] N. N. Greenwood and A. Earnshaw, Chemistry of the Elements, vol. 1132, Butterworth Heimemann, Oxford, UK, 2nd edition, 1997.

[40] A. A. Al-Amiery, Y. K. Al-Majedy, H. Abdulreazak, and H. Abood, "Synthesis, characterization, theoretical crystal structure, and antibacterial activities of some transition metal complexes of the thiosemicarbazone (Z)-2-(pyrrolidin-2-ylidene)hydrazinecarbothioamide," Bioinorganic Chemistry and Applications, vol. 2011, Article ID 483101, 6 pages, 2011.

[41] D. W. Smith, "Polarized crystal spectrum of pentaamminecupric ammonium perchlorate," Inorganic Chemistry, vol. 5, no. 12, pp. 2236-2238, 1966.

[42] A. J. Bard and L. R. Izatt, Electrochemical Methods Fundamentals and Applications, Wiley, New York, NY, USA, 2nd edition, 2001.

[43] B. W. Rossiter and J. F. Hamilton, Physical Methods of Chemistry, Electrochemical Methods, Willey, New York, NY, USA, 1986.

[44] S. A. Patil, V. H. Naik, A. D. Kulkarni, and P. S. Badami, "Spectroscopic, DNA cleavage and antimicrobial studies of $\mathrm{Co}(\mathrm{II}), \mathrm{Ni}(\mathrm{II})$ and $\mathrm{Cu}(\mathrm{II})$ complexes of sulfur donor schiff bases," Journal of Sulfur Chemistry, vol. 31, no. 2, pp. 109-121, 2010.

[45] N. Dharmaraj, P. Viswanathamurthi, and K. Natarajan, "Ruthenium(II) complexes containing bidentate Schiff bases and their antifungal activity," Transition Metal Chemistry, vol. 26, no. 1-2, pp. 105-109, 2001.

[46] D. H. Petering, "Carcinostatic copper complexes," in Metal Ions in Biological Systems, H. Sigel, Ed., Marcel Dekker, New York, NY, USA, 1973.

[47] M. J. Waring, "Structural and conformational studies on quinoxaline antibiotics in relation to the molecular basis of their interaction with DNA," in Drug Action at the Molecular Level, 
G. C. K. Roberts, Ed., vol. 166, pp. 167-189, Macmillan, London, UK, 1977.

[48] A. Kulkarni, S. A. Patil, and P. S. Badami, "Synthesis, characterization, DNA cleavage and in vitro antimicrobial studies of $\mathrm{La}(\mathrm{III}), \mathrm{Th}(\mathrm{IV})$ and VO(IV) complexes with Schiff bases of coumarin derivatives," European Journal of Medicinal Chemistry, vol. 44, no. 7, pp. 2904-2912, 2009. 

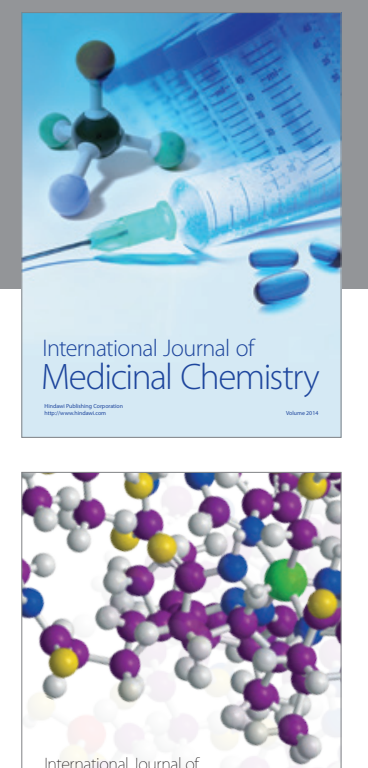

\section{Carbohydrate} Chemistry

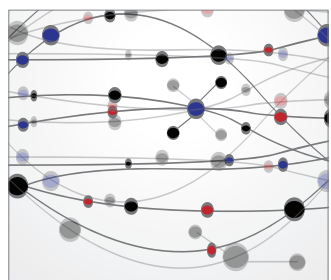

The Scientific World Journal
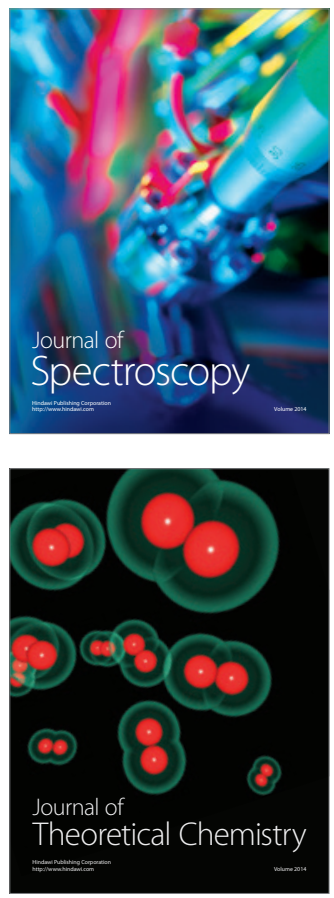
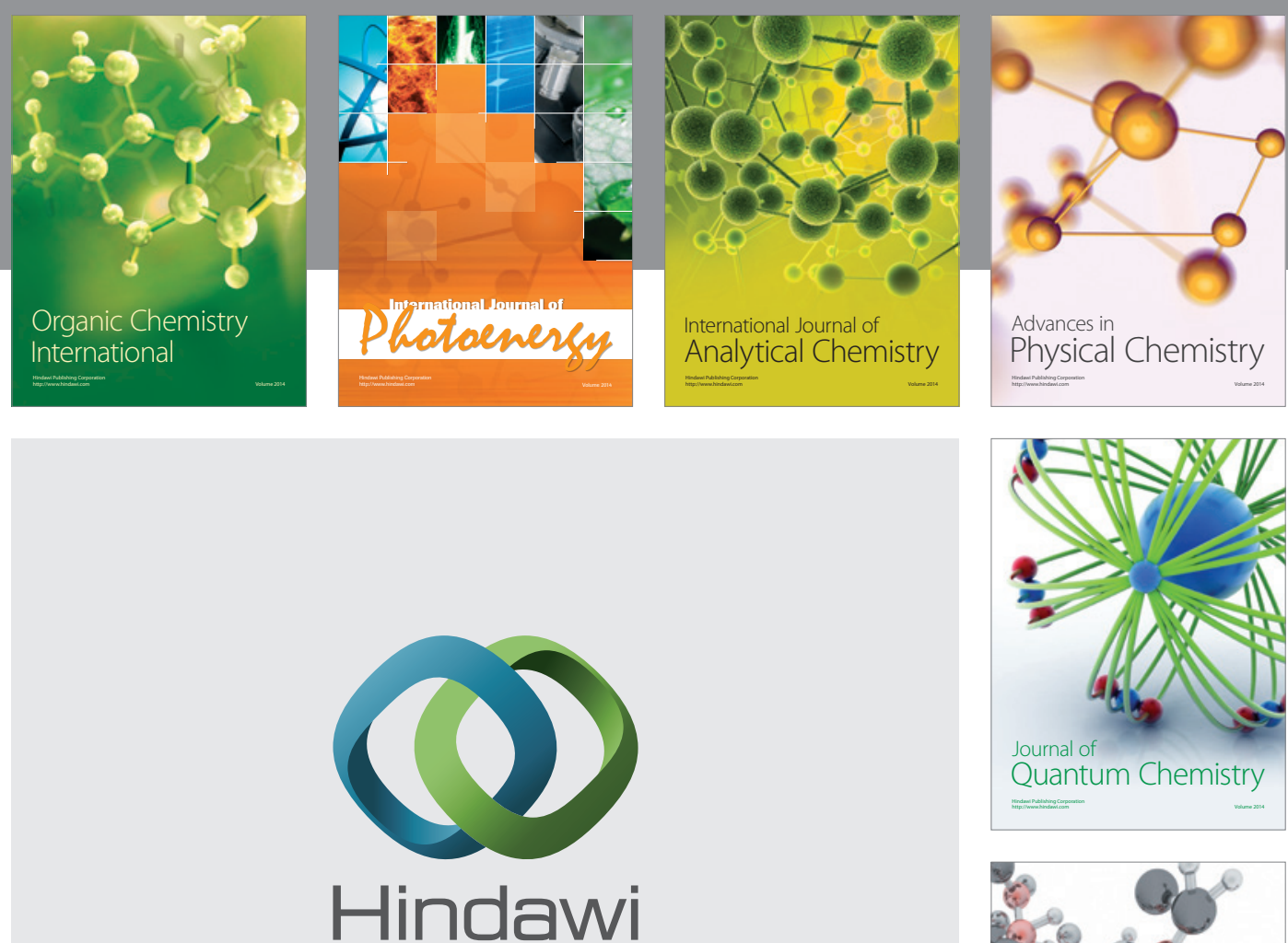

Submit your manuscripts at

http://www.hindawi.com

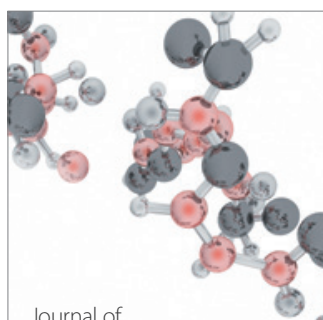

Analytical Methods

in Chemistry

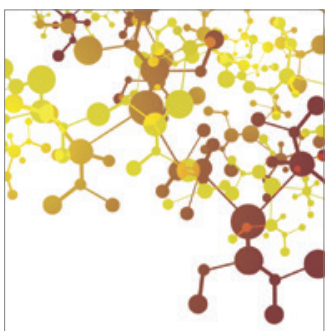

Journal of

Applied Chemistry

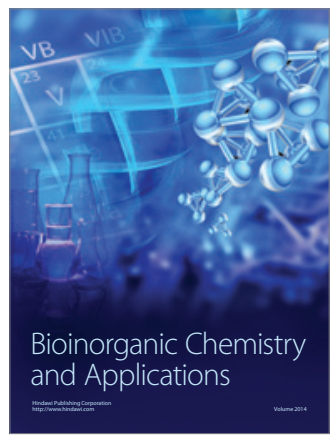

Inorganic Chemistry
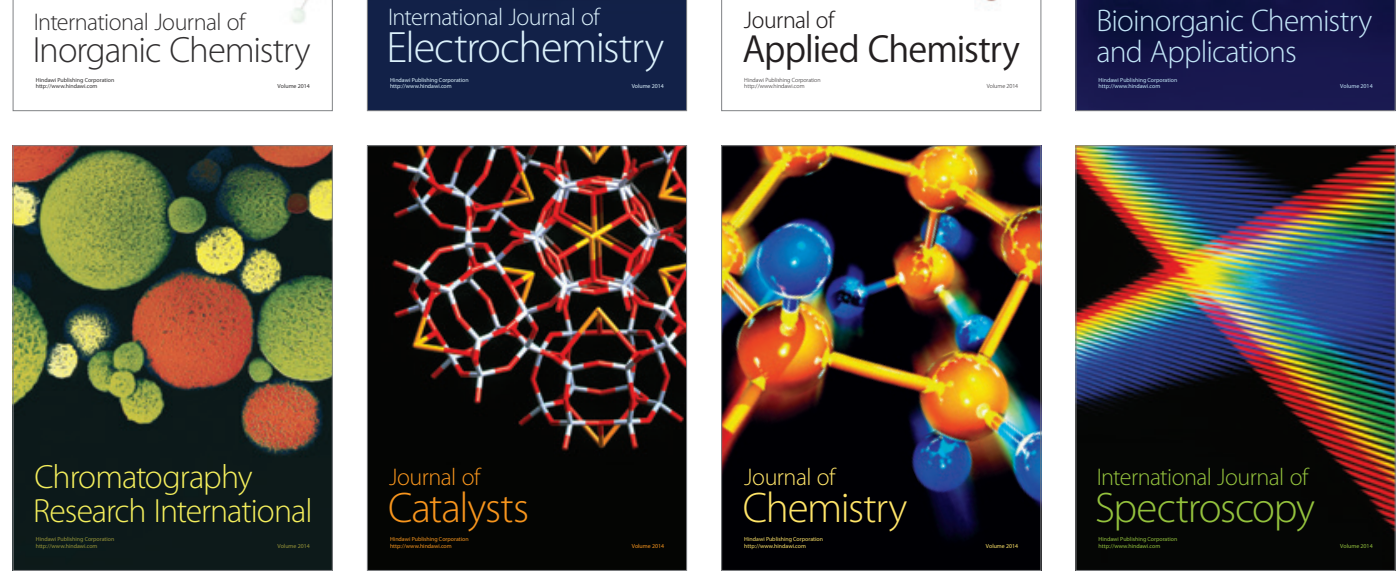